\title{
Hoe Galileo Galilei de valwet ontdekte, en het verschil dat dit maakt
}

Maarten Van Dyck

[Gepubliceerd in Algemeen Nederlands Tijdschrift voor Wijsbegeerte 113 (1), pp.81-105, 2021]

\section{Samenvatting}

De valwet van Galilei is een van de fundamentele bouwstenen voor klassieke mechanica. De vraag hoe die wet ontdekt werd is vaak inzet geweest van discussie. Dit artikel biedt een reconstructie van de ontwikkelingen in Galilei's onderzoek die tot de ontdekking van de valwet leidden. Deze reconstructie staat in dienst van een filosofisch punt met betrekking tot het statuut van experimentele resultaten: het is enkel door hun plaats in een ruimer onderzoeksprogramma dat Galilei's experimenten voldoende verantwoording konden bieden voor de aanvaarding van de valwet.

\section{Galilei's valwet}

Galilei's valwet stelt dat objecten in een vrije val steeds een afstand afleggen die recht evenredig is met het kwadraat van de tijd die nodig was voor die beweging. Deze wiskundige regelmaat in de versnelling van de valbeweging werd door Galileo Galilei ontdekt in de periode tussen 1592 en 1602, en voor het eerst gepubliceerd in zijn Dialoog over de twee voornaamste wereldsystemen uit 1632, maar de meest uitgebreide behandeling komt voor in zijn Vertogen en wiskundige demonstraties over twee nieuwe wetenschappen uit 1638 (verder verwijzen we naar deze tekst als de Discorsi, met zijn Italiaanse titel).

Voor Galilei waren er reeds andere wiskundige wetmatigheden gekend die het gedrag van fysische objecten karakteriseren: in de astronomie konden de banen van planeten wiskundig voorspeld worden, in de mechanica vormde de hefboomwet van Archimedes de basis van een wiskundige behandeling van het functioneren van allerlei machines die gebruik maken van hefbomen, katrolsystemen en tandwielmechanismen, en in de optica waren er ook elementaire wiskundige inzichten bereikt over de voortplanting van licht en de perspectivistische en spiegeleffecten die daarbij optreden. Het belangrijkste verschil ligt in de omstandigheden waaronder die wiskundige regelmatigheden op te merken zijn. De belangrijkste grootheden die in de optica bepaald moeten worden zijn afstanden en hoeken, in de mechanica kan je de wetmatigheden nagaan door afstanden te meten en te kijken of er evenwicht of onevenwicht optreedt in het systeem, en in de astronomie volstaat het om de relatieve hoekafstanden tussen de hemellichamen te meten. Enkel in het laatste geval is tijd ook een relevante factor, maar dit tijdsverloop is uit te drukken door te verwijzen naar de uniforme beweging van hemellichamen. Galilei's valwet is de eerste wet waarin veranderingen doorheen willekeurige tijdsintervallen onderwerp werden van een wiskundige behandeling. Het is pas 
op dit moment dat het tijdsverloop een integraal deel van een wiskundige theorie werd, en dat de ambitie om de volledige natuurlijke werkelijkheid wiskundig te vatten denkbaar werd.

Hoe Galilei de valwet ontdekte lijkt op het eerste gezicht een eenvoudige vraag. Ongetwijfeld is het antwoord: door afstanden en tijden te meten en die met elkaar in verband te brengen. Dat eenvoudige antwoord roept echter nieuwe vragen op. Waarom zou iemand die metingen willen uitvoeren - vanwaar de veronderstelling dat er daar iets interessants uit te leren valt? En gesteld dat je daarvan overtuigd bent, hoe ga je die tijden dan meten op een manier die precies genoeg is? En hoe beslis je eigenlijk wanneer een meting "precies genoeg" is?

Wie naar de natuurlijke werkelijkheid kijkt, wordt geconfronteerd met een grote diversiteit aan fenomenen, elk met hun eigen graad van regelmaat: van weerpatronen tot de verkleuring van bladeren aan bomen en het tollen van een draaitol. De uitdaging voor wetenschappelijke theorievorming is om te achterhalen welke van deze fenomenen het meest informatief zijn. Welke tonen eigenschappen die ons toelaten om ook andere fenomenen te begrijpen? Hoe kunnen we ervoor zorgen dat ze die eigenschappen ook werkelijk tonen? En gesteld dat we denken hun eigenschappen achterhaald hebben, hoe kunnen we die dan vruchtbaar gebruiken om verdere fenomenen te begrijpen?

Hoe Galilei de valwet ontdekte is het het verhaal over hoe Galilei een begin van een succesvol praktisch antwoord op die vragen wist te formuleren.

\section{Voerde Galilei experimenten uit?}

De vraag of Galilei werkelijk experimenten uitvoerde om zijn valwet aan te tonen is, misschien wel verrassend, de inzet geweest van een belangrijk wetenschapshistorisch debat in de twintigste eeuw. Centraal daarbij stond de vraag naar de steeds betwistbare precisie van experimentele resultaten. Galilei gaf zelf in de Discorsi de volgende beschrijving van een experiment om zijn valwet te ondersteunen:

In een houten balk of daklijst van twaalf armlengtes ${ }^{1}$ lengte, met een breedte van een halve armlengte en een dikte van drie vingers, werd langs de smalste zijde een groef gemaakt van iets meer dan een vinger breedte; die werd erg recht gemaakt, en om ze goed proper en glad te houden werd er een stuk perkament ingeplakt dat zo goed als mogelijk proper en glanzend gemaakt was. Hierin deden we een goed gepolijste en propere harde bronzen bal afdalen door de balk te hellen, met één zijde op een willekeurig manier één of twee armlengtes boven het horizontale vlak getild. Terwijl we zoals gezegd de bal lieten afdalen langs de groef bepaalde we de tijd (op een manier die ik zo meteen zal toelichten) die het gebruikte in het afleggen van

\footnotetext{
${ }^{1}$ De exacte maat hiervan is niet belangrijk (en ook verschillend per regio), maar een braccia of armlengte (een "el") is in de grootte-orde van iets meer dan een halve meter.
} 
de hele weg. We herhaalden dat vele malen om zeker te zijn over de hoeveelheid tijd, waarbij we niet meer verschil konden opmerken dan zelfs een tiende van een polsslag.

Nadat we dat gedaan en gestabiliseerd hadden, deden we dezelfde bal afdalen over slechts een vierde deel van de lengte van de groef; en de tijd van zijn afdaling gemeten, vonden we steeds dat die exact de helft van de eerdere tijd was. En toen we daarna het experiment deden voor andere lengtes, en de tijden voor de hele lengte vergeleken met die voor de halve lengte, of die voor een derde daarvan of voor drie vierde, of, om te concluderen, die voor eender welk deel, dan blijkt uit de experimenten die we wel honderd keer herhaalden, dat de afgelegde afstanden steeds tot elkaar de verhouding hadden van de kwadraten van de tijden, en dat voor alle hellingen van het vlak (en dus ook van de groef langs dewelke de bal moest afdalen) ... Wat nu de meting van de tijd betreft, we gebruikten een groot vat gevuld met water, op een hoogte vastgemaakt, waaruit door een nauwe tube die verbonden was aan de bodem een smal straaltje water stroomde dat opgevangen werd in een kleine beker gedurende de gehele tijd dat de bal afdaalde in de groef of doorheen delen daarvan. De kleine hoeveelheden water die op die manier verzameld werden, werden daarna keer op keer gewogen met een zeer exacte weegschaal zodat de verschillen en verhoudingen van hun gewichten de verschillen en verhoudingen van de tijd aangaven; en dat met zo'n precisie, dat, zoals ik zei, die handelingen, vele keren herhaald, nooit verschilden met enig merkbaar moment. (Galilei, 1890, vol. 8, pp. 212-213)

Het debat werd geopend door de Frans-Russische wetenschapshistoricus Alexandre Koyré, die na deze passage geciteerd te hebben, opmerkte:

A bronze ball rolling in a "smooth and polished" wooden groove! A vessel of water with a small hole through which it runs out and which one collects in a small glass in order to weigh it afterwards and thus measure the times of descent (the Roman water-clock, that of Ctesebius, had been already a much better instrument): what an accumulation of sources of error and inexactitude!

It is obvious that the Galilean experiments are completely worthless: the very perfection of their results is a rigorous proof of their incorrection. (Koyré, 1953, p. 224)

Dat Galilei beweerde perfecte resultaten te bereiken met zulke primitieve middelen, toont volgens Koyré enkel aan dat hij de experimenten nooit werkelijk uitvoerde! Zoals Koyré in een voetnoot bij die bewering verduidelijkte, kunnen we het onderscheid maken tussen twee vragen: wat is het proces dat Galilei tot de formulering van zijn valwet leidde? En hoe trachtte hij zijn wet empirisch te ondersteunen? Maar aangezien zelfs de ondersteuning volgens Koyré al volledig imaginair was, meende hij dat de bewering dat Galilei zijn wet op een empirische manier zou hebben gevonden helemaal vergezocht was. 
Deze aanval op de empirische gronden van Galilei's valwet paste binnen het kader van de invloedrijke interpretatie die Koyré vanaf de jaren dertig ontwikkelde van het werk van Galilei, en van de wetenschappelijke revolutie van de zeventiende eeuw in het algemeen. Volgens hem was dat in de eerste plaats een metafysische revolutie, gesteund op de door Plato geïnspireerde overtuiging dat de werkelijkheid wiskundig van aard moest zijn. Empirische ondersteuning werd pas mogelijk eenmaal er vanuit die overtuiging voldoende theorie ontwikkeld was (bijvoorbeeld over hoe goede klokken te construeren) om metingen uit te voeren die wel exact genoeg konden zijn. Galilei's theorieën konden op het moment dat hij ze formuleerde niet meer dan hypothetisch zijn, het resultaat van een rationele gok die achteraf gezien de juiste bleek te zijn.

In 1961 toonde een Amerikaanse doctoraatsstudent echter aan dat het experiment zoals beschreven door Galilei wel degelijk tot relatief precieze resultaten kan leiden, door een eenvoudige reconstructie op te zetten (Settle, 1961). Vanaf de vroege jaren zeventig begon een aantal onderzoekers bovendien een systematische studie van de zogenaamde Codex 72, een verzameling manuscriptnotities van Galilei die slechts partieel opgenomen waren in de editie van zijn volledige werken, waaruit bleek dat Galilei effectief experimenten met hellende vlakken opzette en de resultaten ervan noteerde (zie o.a. Drake (1973)) - al bevatten de bewaarde manuscripten wel geen directe neerslag van het experiment zoals beschreven in de Discorsi. ${ }^{2}$

Het is dus een historisch feit dat Galilei experimenten met hellende vlakken uitvoerde en een fysisch feit dat de resultaten van de in de Discorsi beschreven experimenten ook relatief plausibel zijn. Kunnen we daaruit besluiten dat het debat beslecht is? Dat hangt af van wat daarvan de werkelijke inzet was. De simpele vraag of Galilei al dan niet experimenten uitvoerde kunnen we beantwoorden. De provocatieve vraag of hij in zijn Discorsi een louter imaginair experiment beschreef dat zijn theorie dus onmogelijk empirisch kon ondersteunen, kunnen we ook beantwoorden. Maar op de vraag hoe zijn valwet ontdekte hebben we nog geen antwoord. Bovendien zullen we zien dat een directe poging om die vraag te beantwoorden kan helpen om verder na te denken over wat het betekent om te zeggen dat het experiment met het hellende vlak een empirische ondersteuning kon bieden van de valwet.

\section{Het vertrekpunt: versnelling als bijkomstig fenomeen}

Galilei begon zijn zoektocht naar de wiskundige structuur van bewegingsfenomenen in een traktaat dat hij als twintiger in de jaren 1589-92 schreef maar nooit publiceerde, en dat bekend staat als De Motu

\footnotetext{
${ }^{2}$ De volledige Codex 72 is gedigitaliseerd en online consulteerbaar: http://www.imss.fi.it/ms72/index.html. Büttner (2019) bevat een gedetailleerde studie die alle voorgaande analyses overtreft in historische en analytische gestrengheid.
} 
Antiquiora (Galilei, 1890, vol. 1, pp. 243-419). ${ }^{3}$ Het opvallendste daarin is dat hij de stelling verdedigde dat vrije val in essentie een beweging is met een uniforme snelheid. Dat was een onmiddellijk gevolg van zijn keuze om de regelmaat zoals opgemerkt in het drijven en zinken van objecten in vloeistoffen als vertrekpunt te nemen voor zijn zoektocht. Die regelmaat was reeds in de oudheid wiskundig beschreven door Archimedes in de theorie van de hydrostatica. Die theorie geeft een eenvoudig criterium om na te gaan of een object zal zinken in een vloeistof: weeg het object en weeg een hoeveelheid van de vloeistof die hetzelfde volume heeft als het object - indien het eerste gewicht groter is dan het tweede zal het object zinken, anders niet. Galilei extrapoleerde uit die gekende regelmaat een nieuwe hypothese: dat de snelheid waarmee een object zich door een medium beweegt steeds evenredig zal zijn met het verschil tussen die twee gewichten. Een eenvoudig voorbeeld hiervan is een object in vrije val doorheen de lucht. Aangezien daarbij zowel het gewicht van het object als dat van een gelijk volume van de lucht niet veranderen tijdens de beweging van het object, zal de snelheid van de vrije val dus ook uniform moeten blijven. Kort samengevat kunnen we stellen dat Galilei een andere invulling gaf dan zijn voorgangers van de bewegingskracht aanwezig tijdens het fenomeen van vrije val (waarbij volgens hem het medium een deel van het gewicht van het vallende object neutraliseert), maar dat hij vasthield aan het gangbare idee dat een uniforme kracht een uniforme snelheid veroorzaakt.

Het vraagt geen gesofisticeerde experimenten om op te merken dat vrij vallende objecten versnellen tijdens hun valbeweging. Uit de tekst blijkt dat Galilei zich daarvan goed bewust was. Die versnelling was volgens hem echter het gevolg van de volgende complicatie. Voordat een object kan beginnen te vallen, moet het in de hoogte gehouden worden op een manier die zijn natuurlijke valbeweging tegengaat, en hiervoor moet er een kracht op uitgeoefend worden. Tijdens het begin van de valbeweging is die uitgeoefende kracht nog aanwezig in het object en vertraagt ze de val, maar ze dooft ook gradueel uit. Het is dat gradueel uitdoven van de uitgeoefende kracht dat zich in de versnelling toont, maar eenmaal ze volledig verdwenen is, zal het object verder vallen met een uniforme snelheid. De empirisch op te merken versnelling was voor Galilei enkel een bijkomstig fenomeen dat de onderliggende wiskundig structuur moeilijker zichtbaar maakte. Het idee van een uitdovende kracht werd al lang voor Galilei geïntroduceerd om te begrijpen waarom elk object dat door een externe kracht in beweging gebracht wordt, na verloop van tijd terug tot stilstand komt. Het was dus niet zomaar een ad hoc hypothese waarop Galilei zich enkel beriep om de geobserveerde versnelling weg te verklaren, maar het maakte deel uit van de fysische principes die ruim aanvaard werden.

In De Motu Antiquiora behandelde Galilei nog twee andere fenomenen, allebei gerelateerd aan zijn behandeling van vrije val: de beweging van een object op een hellend vlak, en de baan van een projectiel.

\footnotetext{
${ }^{3}$ Zie Fredette (2001) voor een situering van deze tekst.
} 
Kanonnen werden in de zestiende eeuw steeds frequenter gebruikt in de oorlogsvoering, en de vraag naar de baan afgelegd door een kanonskogel kon dan ook op veel belangstelling rekenen. Galilei nam in de grote lijnen de theorie over van een voorganger, Nicolò Tartaglia (zie figuur 1). Ook hier beriep hij zich het idee dat een uitgeoefende kracht nog een tijdje aanwezig blijft in een object (hier de kanonskogel), maar gaandeweg uitdooft. Initieel hebben we te maken met een gewelddadige beweging die quasi rechtlijnig verloopt, maar nadat de kracht grotendeels is uitgedoofd wordt de baan afgebogen onder de toenemende invloed van het gewicht, totdat het gewicht de beweging volledig domineert, en we terug met een vrije val te maken hebben.

De introductie van de beweging op een hellend vlak in een traktaat over natuurlijke beweging was een innovatie van Galilei. De belangrijkste reden dat hij het behandelde in zijn tekst is dat hij dit fenomeen op een gelijkaardige manier kon verklaren als dat van de beweging in een medium: het hellende vlak neutraliseert net zoals het medium een deel van het gewicht van een object. Bovendien kon ook hier op een wiskundig exacte manier bepaald worden wat de grootte van dat effect is. Om dat te doen beeldde Galilei zich in dat het object op een hellend vlak in evenwicht gehouden wordt met behulp van een balans met een gebogen arm, wat hem toeliet om het effectief werkzame gewicht van het object te bepalen (zie figuur 2). Aangezien het effectieve gewicht van een object op verschillende hellende vlakken een maat geeft voor de kracht waarmee het object naar beneden tracht te bewegen, kon Galilei hieruit opnieuw conclusies trekken over de snelheid van de resulterende bewegingen, door ervan uit te gaan dat die snelheden in dezelfde verhouding tot elkaar staan als de krachten verantwoordelijk voor de bewegingen. Hoe steiler de helling van het vlak, hoe sneller een object erop zal bewegen, op een exact te bepalen manier.

\section{De weg naar de valwet}

\subsection{De parabolische baan van een projectiel}

In 1592 bezocht Galilei zijn mentor, de Italiaanse wiskundige Guidobaldo del Monte, en voerde samen met hem een klein experiment uit om meer te weten te komen over de vorm van projectielbanen. ${ }^{4} \mathrm{Ze}$ doopten een bal in inkt en wierpen hem zodanig dat hij tijdens zijn beweging over de het schuine vlak van een dak een inktspoor naliet. Del Monte vatte hun bevindingen samen in zijn notitieboek:

Indien men een bal boven de horizontale lijn werpt, met een katapult, met behulp van artillerie, met de hand, of met een ander instrument, dan volgt die in het vallen hetzelfde pad als in het

\footnotetext{
${ }^{4}$ Dat Galilei betrokken was bij dat experiment, waarvan de neerslag te vinden is in een notitieboek van Guidobaldo del Monte, werd reeds langer vermoed, maar is voor het eerst overtuigend aangetoond in Renn et al. (2000).
} 
stijgen. De vorm ervan is diegene die omgekeerd onder de horizontale lijn een touw maakt waaraan niet getrokken wordt [en dat vrij aan zijn twee uiteinden opgehangen is]. Beide zijn samengesteld uit zowel het natuurlijke als het gewelddadige, en de lijn is op het zicht gelijkend op een parabool en hyperbool. (Geciteerd in Renn et al. (2000, p. 314).)

Del Monte en Galilei gingen er nog steeds vanuit dat de uitgeoefende, "gewelddadige", werpkracht in het projectiel aanwezig bleef, en gradueel uitdoofde. Ze merkten echter op dat het natuurlijke gewicht van het object van bij aanvang interageerde met die werpkracht, en wel op zo een manier dat het resulterende traject een symmetrische vorm had, in duidelijke tegenstelling tot de ideeën van Tartaglia die Galilei nog volgde in zijn De Motu Antiquiora. Hierdoor werd het mogelijk om ervan uit te gaan dat het volledige traject misschien te beschrijven viel met één unieke wiskundige curve zoals gekend uit de antieke meetkunde.

Op het moment dat Del Monte zijn notitie neerschreef liet hij nog open of die curve een parabool of een hyperbool was, maar Galilei zou in het decennium dat volgde zonder verdere twijfel voor de parabool opteren. Wanneer we de symmetrie-as van de parabool als $y$-as nemen en loodrecht daarop een $x$-as definiëren (bijvoorbeeld de raaklijn in het hoogste punt), dan wordt die curve gekarakteriseerd door een kwadratische vergelijking: ${ }^{5} y=x^{2}$. Indien we de afstanden langs de $x$-as als tijden zouden kunnen interpreteren, dan geeft de parabool ons dus direct de valwet!

Galilei noch Del Monte lijkt die conclusie getrokken te hebben in 1592 of de jaren onmiddellijk daarna. ${ }^{6}$ Om dat te kunnen doen moet het traject van het projectiel geïnterpreteerd worden als de samenstelling van een uniforme beweging volgens de horizontale richting (waardoor gelijke afstanden langs de $x$-as overeenkomen met gelijke tijden) en een versnelde beweging volgens de verticale richting. Maar Galilei en Del Monte interpreteerden de baan als het resultaat van de samenstelling van een vertragende gewelddadige beweging volgens de richting waarin het projectiel werd weggeworpen en een uniforme natuurlijke beweging volgens de verticale richting. Het uitdoven van de uitgeoefende kracht dat verantwoordelijk is voor de versnelling in de neerwaartse beweging werd dan wel gekenmerkt door een eigen wiskundige wetmatigheid, maar die was nog ongerelateerd aan Galilei's valwet. Het is niet toevallig dat het tijdsverloop nergens expliciet vernoemd werd in de beschrijving die Del Monte geeft.

\subsection{De isochronie van de slinger}

\footnotetext{
${ }^{5}$ Deze formulering in termen van cartesische coördinaten en algebraïsche vergelijkingen gebruikt een taal die niet die van Galilei en Del Monte is, maar de ideeën konden ook uitgedrukt worden in hun proportionele en geometrische taal.

${ }^{6}$ Renn et al. (2000) suggereren het tegendeel, maar kunnen daarvoor geen direct bewijsmateriaal aandragen.
} 
Tien jaar na hun gezamenlijke projectielexperiment wisselden Galilei en Del Monte in de herfst van 1602 een aantal brieven uit over een nieuw idee van Galilei. De enige bewaarde brief uit die correspondentie is de belangrijkste getuige van een cruciaal moment in de ontwikkeling van Galilei's denken (Galilei, 1890, vol. 10, pp. 97-100). Plots ging zijn aandacht uit naar de relatie tussen de beweging van een bal aan een slinger en die van een bal op een hellend vlak. Daarbij stond de bewering centraal dat de beweging van een slinger isochroon is.

Indien twee loden ballen aan een even lange draad opgehangen worden, en met gestrekte draad vanop een verschillende hoogte losgelaten worden, zullen ze een slingerbeweging maken waarbij de ene een grotere cirkelboog volgt dan de andere. Ondanks het verschil in de lengte van hun baan, zullen de ballen toch synchroon met elkaar blijven slingeren: de langere cirkelboog wordt steeds in dezelfde tijd afgelegd als de kortere. Galilei's bewering dat hij observeerde dat dit geldig blijft na honderd slingeringen is ongetwijfeld een overdrijving. Bovendien weten we ondertussen dat die eigenschap van isochronie enkel geldig is voor bewegingen over kleine cirkelbogen - iets wat op empirische gronden reeds benadrukt werd door tijdgenoten van Galilei. Maar we zullen zien dat er voor Galilei een goede reden was waarom hij, ondanks Del Montes scepticisme, meende dat het fenomeen dat enkel bij benadering geobserveerd kon worden, toch strikt genomen waar was.

In De Motu Antiquiora had Galilei reeds kort naar een slingerbeweging verwezen om het gradueel uitdoven van een uitgeoefende kracht te illustreren: een slinger zal initieel de kracht behouden die hem uit zijn evenwichtstoestand had gebracht, maar zal na verloop van tijd steeds terug tot stilstand komen. Volgens dit idee zal ook de slinger in zijn neerwaartse beweging een versnelling kennen die opnieuw het gevolg is van de graduele uitdoving van de bewegingskracht. Het fenomeen van de isochronie moet hierop een verrassend nieuw licht geworpen hebben voor Galilei. Als een slingerende bal steeds evenveel tijd nodig heeft om op zijn laagste punt te komen, onafhankelijk van de lengte van zijn pad, dan moet die versnelling gekenmerkt worden door een onderliggende vaste regelmaat die hiervoor verantwoordelijk is!

\subsection{Versnelling als centraal fenomeen voor een nieuwe wetenschap}

Op dit moment had Galilei twee nieuwe empirische fenomenen opgemerkt die onafhankelijk van elkaar suggereerden dat er een wiskundige regelmaat aan te treffen was in de versnelling die zware objecten ondergaan in hun neerwaartse beweging. Bovendien kon de beweging van een slinger op een interessante manier in verband gebracht worden met de beweging op hellende vlakken die hij al in $D e$ Motu Antiquiora had behandeld. In een tekst over mechanica die hij ergens in de periode na 1592 schreef (dus na De Motu Antiquiora, en waarschijnlijk voor de brief aan Del Monte) nam hij die figuur en de bijhorende analyses van evenwicht op een hellend vlak opnieuw op. Daaraan voegde hij ditmaal 
echter de volgende cruciale opmerking toe (met de indices aangepast om in overeenstemming te zijn met die van figuur 2):

Je kunt dus zien hoe een gewicht geplaatst aan het uiteinde van lijn $a d$, neerwaarts bewegend langs de cirkelomtrek $d s r b$, gradueel zijn momentum en zijn impetus om naar beneden te bewegen ziet afnemen, aangezien het meer en meer ondersteund wordt door de lijnen $a s$ en ar. ${ }^{7}$ Maar het is niet verschillend om dat zware object te beschouwen terwijl het daalt en nu eerst minder en dan meer ondersteund wordt door de halve diameters as en ar, en dus zo gedwongen wordt om langs de omtrek $d s r$ te bewegen, of om in te beelden dat dezelfde cirkelomtrek $d s r b$ een oppervlak is met die kromming dat onder het bewegende object geplaatst is, zodanig dat het object, ondersteund door dat oppervlak, gedwongen wordt om langs het oppervlak te bewegen. Aangezien het bewegende object in beide gevallen hetzelfde pad zal volgen, makkt het niet uit of het opgehangen is vanuit het centrum $a$ en ondersteund door de halve diameter van de cirkel, of dat die ondersteuning is weggenomen en het ondersteund wordt door en beweegt langs de omtrek $d s r b$.... Als het object zich bij het punt $s$ bevindt, dan wordt zijn gewicht gedeeltelijk ondersteund door het circulaire pad dat onder hem ligt, en wordt zijn momentum om naar beneden te bewegen verminderd ... maar op het eerste punt van de resulterende beweging is die beweging alsof ze plaatsvond op een hellend vlak dat georiënteerd is zoals de raaklijn gsh, aangezien de helling van de cirkelomtrek in het punt $s$ niet verschilt van die van het hellende vlak ... (Galilei, 1890, vol. 2, p. 182)

Volgens een vaak aangehaalde legende zou Galilei de isochronie van de slinger ontdekt hebben terwijl hij als jongeman naar een slingerende kandelaar in de kathedraal van Pisa keek. Zelfs als dat verhaal een kern van waarheid zou bevatten (wat we nooit zullen kunnen achterhalen), dan nog moeten we opmerken dat het maar op het moment is dat hij vanuit bovenstaand perspectief naar dit fenomeen keek dat het ten volle fysisch relevant werd. Het is door de relatie die hij hier opmerkte tussen een slingerbeweging en bewegingen op hellende vlakken (die telkens georiënteerd zijn zoals de opeenvolgende raaklijnen aan de cirkelomtrek) dat de regelmaat in de eigenschappen van de slinger informatief kan worden voor die rechtlijnige bewegingen - en vice versa. Op het moment dat Galilei zijn brief aan Del Monte schreef, was hij reeds begonnen met het verstrekkende project om te trachten die potentiële informatie ten volle te exploiteren.

Aangezien Galilei er nu waarschijnlijk van overtuigd was dat versnelling een wiskundige regelmaat kende, en dat er een relatie moest zijn tussen de beweging op hellende vlakken en die van een slinger, is het erg waarschijnlijk dat hij op dit punt het experiment met het hellende vlak opzette

\footnotetext{
${ }^{7}$ Momentum en impetus zijn belangrijke termen om Galilei's denken volledig accuraat te begrijpen. Ze mogen in ieder geval niet gelijkgesteld worden met begrippen uit de hedendaagse fysica die met dezelfde termen aangeduid worden.
} 
om meer informatie te achterhalen over die regelmaat, met het gekende resultaat: de neerwaartse versnelling van een zwaar object wordt bij benadering gekenmerkt door een kwadratische relatie tussen afgelegde afstanden en verstreken tijden.

\section{De valwet en de nieuwe wetenschap}

\subsection{De slingerbeweging en beweging op hellende vlakken ${ }^{8}$}

In de brief aan Guidobaldo del Monte uit 1602 communiceerde Galilei reeds twee opmerkelijke resultaten die hem ervan overtuigden dat het mogelijk moest zijn om de relatie tussen de beweging op hellende vlakken en de slingerbeweging informatief te analyseren. De eerste stelling was de volgende. Wanneer in een rechtopstaande cirkel twee punten in de onderste helft van de cirkel genomen worden, zoals bijvoorbeeld de punten $r$ en $s$ in figuur 2, en er vanuit die punten hellend vlakken geconstrueerd worden die eindigen in het punt waarin de cirkel de horizon raakt (punt $b$ in diezelfde figuur), dan zullen twee ballen die via die hellende vlakken afdalen hun beweging ook steeds in dezelfde tijd voltooien. Het is niet te achterhalen hoe Galilei initieel tot deze stelling kwam (zie Büttner (2019, hoofdstuk 8) voor discussie), maar in zijn Discorsi zal hij het later afleiden uit zijn valwet en een extra aanname. Uiteraard volgen de slingerende ballen en de ballen die via de hellende vlakken afdalen een ander pad. Toch is het plausibel om er zoals Galilei van overtuigd te zijn dat er een niet-toevallige relatie moest zijn tussen beide fenomenen van isochrone bewegingen. Het is ongetwijfeld deze relatie die hem er ook toe bracht om de afwijkingen van isochronie voor slingerbewegingen met een grotere uitwijking toe te schrijven aan toevallige verstoringen: de isochronie van de bewegingen op hellende vlakken was immers ook niet afhankelijk van de hellingsgraad van de vlakken.

De tweede stelling in de brief aan Del Monte was op zijn minst even verrassend. Het cirkelvormige slingerpad kan benaderd worden door steeds meer hellende vlakken te introduceren, door bijvoorbeeld het hellende vlak $s r$ toe te voegen, waardoor het rechtlijnige traject $s r b$ de cirkelomtrek dichter benadert dan $s b$. Galilei schreef dat hij weliswaar nog niet in staat was om op deze manier "te bewijzen hoe de cirkelomtrekken $s r b$ en $r b$ in evenveel tijd gepasseerd worden, en dat is waar ik naar op zoek ben" (Galilei, 1890, vol. 10, p. 99), maar hij had al wel kunnen aantonen dat het rechtlijnige traject $s r b$ steeds in minder tijd afgelegd wordt dan het nochtans kortere hellende vlak $s b$. Ook deze stelling, die hij kon afleiden gebruik makende van zijn valwet, leek direct relevant voor een analyse van de slingerbeweging. Zijn manuscriptnotities uit deze periode bevatten immers de neerslag van een interessant experiment dat aantoonde dat de slinger inderdaad opvallend sneller zijn

\footnotetext{
${ }^{8}$ Büttner (2019) bevat een baanbrekende analyse van de evoluties in Galilei's onderzoek naar de relatie tussen de slingerbeweging en de beweging op hellende vlakken, waarop de volgende sectie in de grote lijnen steunt.
} 
laagste punt bereikte over slingerboog $s b$ dan een bal die over hellend vlak $s b$ afdaalde (zie Büttner (2019, hoofdstuk 4)). Dit experiment bracht hem er toe om ook de verdere hypothese te onderzoeken dat de cirkelvormige slinger niet enkel isochroon is, maar dat het ook de brachistochroon is: het pad langs hetwelk een zwaar object in de kortste tijd een bepaalde verticale afstand overbrugt. Net zoals bij de isochronie zou later in de zeventiende eeuw aangetoond worden dat een cirkelvormige slinger niet de brachistochroon is, maar de twee stellingen die Galilei in de brief aan Del Monte communiceerde zouden wel overeind blijven als fysisch geldige uitspraken.

De Discorsi, die Galilei uiteindelijk publiceerde in 1638, bestond uit vier dagen waarin drie protagonisten met elkaar discussieerden over de twee "nieuwe wetenschappen" die door Galilei ontwikkeld waren. De eerste nieuwe wetenschap analyseerde de voorwaarden waaronder massieve objecten breken onder invloed van hun eigen gewicht, zoals een balk die in een muur bevestigd is. De tweede nieuwe wetenschap, die in de twee laatste dagen van het werk behandeld werd, was Galilei's bewegingstheorie zoals hij die in het eerste decennium van de eeuw ontwikkeld had. De derde dag bevatte de slechts ten dele succesvolle uitkomst van het project dat in 1602 aangevangen werd. De isochronie werd er niet in aangetoond, en van de brachistochronie werd met de nodige voorzichtigheid gesteld dat wiskundig bewezen kan worden dat "het erop lijkt" (verisimile est) dat ze geldig is voor de cirkelvormige slinger (Galilei, 1890, vol. 8, p. 263). Toch is de Discorsi een mijlpaal in de geschiedenis van de fysica gebleken, vanwege de valwet die erin geïntroduceerd werd, en de manier waarop aangetoond werd dat daaruit verdere interessante gevolgen getrokken konden worden.

\subsection{De projectielbaan en horizontale beweging ${ }^{9}$}

Zowel het nieuwe experiment met het hellende vlak dat Galilei waarschijnlijk omstreeks 1602 uitvoerde als het oudere over de projectielbaan uit 1592 toonden kwadratische resultaten. In het eerste geval brachten die expliciet afstanden en tijden in verband tot elkaar, in het tweede geval betrof het een relatie tussen verticale en horizontale afstanden. Aangezien de projectielbaan symmetrisch is, en de tweede helft een vallend object betreft, lijkt het voor de hand te liggen om ervan uit te gaan dat de kwadratische relatie die zich daar toont dezelfde is als diegene die het hellende vlak aan het licht bracht. Dat is echter enkel mogelijk indien het zinvol is om de horizontale afstanden als tijden te interpreteren.

Op dit punt kan een ander inzicht dat Galilei reeds in De Motu Antiquiora formuleerde plots extra relevantie hebben gekregen. In de context van zijn analyses van beweging op hellende vlakken had Galilei zich daar de vraag gesteld wat ze impliceerden voor objecten die zich op een horizontaal vlak bevinden. Om een object op een hellend vlak naar boven te doen bewegen is er steeds een kracht nodig die groter is dan het effectieve gewicht van dat object op het vlak. Zoals we hoger zagen heeft

\footnotetext{
${ }^{9}$ De hieropvolgende analyse steunt op Van Dyck (2018).
} 
dat effectieve gewicht dezelfde verhouding tot het absolute gewicht als de hoogte van het hellende vlak tot de lengte ervan. Voor een horizontaal vlak is de laatste verhouding nul, en dus zou de kleinst mogelijke kracht in principe moeten volstaan om het object in beweging te brengen. Die conclusie kon Galilei verder ondersteunen met het volgende gedachte-experiment. Een object dat op een hellend vlak ligt, zal steeds een zekere neiging tot beweging naar beneden hebben, maar die neiging wordt kleiner als de hoek van het hellende vlak afneemt. Datzelfde object zal ook steeds een zekere weerstand hebben tot het in beweging naar boven gebracht worden, maar ook die weerstand wordt kleiner als diezelfde hoek afneemt. In het limietgeval waar de hoek nul graden wordt, zal er geen neiging tot, maar ook geen weerstand tegen beweging zijn. Vanuit het perspectief van dat object is beweging over een horizontaal vlak dus niet natuurlijk (het gevolg van een interne neiging) en ook niet gewelddadig (het gevolg van het overwinnen van een interne weerstand), maar "neutraal" (Galilei, 1890, vol. 1, p. 299).

In De Motu Antiquiora trok Galilei nergens conclusies over de eigenschappen van de beweging die resulteert eenmaal een object op een horizontaal vlak in beweging gebracht is, ook al formuleerde hij een variant van de vraag daarnaar. Terugkijkend vanuit post-galileïsche fysica zouden we kunnen verwachten dat hij kon concluderen dat die beweging steeds moet voortduren, aangezien het object geen weerstand tegen die beweging heeft, en er dus ook geen reden is waarom het zou moeten stoppen indien we alle weerstand veroorzaakt door wrijving en dergelijke wegdenken (en die idealisering had hij reeds expliciet geïntroduceerd, omdat het anders ook niet volgt dat de kleinst mogelijke kracht het object in beweging zou kunnen brengen). Dat hij die conclusie toch niet trok, heeft ongetwijfeld te maken met het feit dat hij ervan overtuigd was dat een uitgeoefende kracht steeds nog een tijd aanwezig blijft in het object waarop de kracht uitgeoefend werd, maar gaandeweg uitdooft. Zou het object dat door die kracht in beweging gebracht was dan niet net moeten stilvallen, aangezien het zelf geen interne neiging tot horizontale beweging heeft? Het lijkt erop dat Galilei niet anders kon dan onbeslist blijven over de vraag hoe de resulterende neutrale beweging te karakteriseren.

Vóór 1602 had Galilei niet voldoende elementen tot zijn beschikking om dit dilemma in zijn bewegingstheorie op te lossen. Na 1602 was hij er echter van overtuigd dat een natuurlijke neerwaartse beweging gekarakteriseerd wordt door de kwadraten-wet. Eenmaal je daarvan uitgaat, is het eenvoudig om in te zien dat je dat in verband kunt brengen met de experimenteel vastgestelde paraboolbaan, op voorwaarde dat je die laatste interpreteert als het gevolg van de samenstelling van een verticaal versnelde beweging en een horizontaal uniforme beweging. Dat geeft je een goede reden om een eenduidig positief antwoord te geven op de vraag of neutrale bewegingen voortduren. Na 1602 gebruikte Galilei het hoger beschreven gedachte-experiment inderdaad om direct te concluderen dat 
horizontale bewegingen uniform zijn, en dus ook zullen voortduren. ${ }^{10}$ Dat betekent dat hij vanaf dan ook het idee van de uitdovende kracht liet vallen - eenmaal je dat doet volgt die conclusie immers zonder veel problemen uit het gedachte-experiment. Op dat moment was de transitie volledig voltrokken om de versnelling van een vallend object niet langer als een accidenteel fenomeen te zien, maar als een natuurlijk kenmerk. ${ }^{11}$

Er is een belangrijke beperking in het gebruik van dit gedachte-experiment om de paraboolbaan wiskundig te analyseren die Galilei nooit achter zich heeft kunnen laten. Enkel wanneer een projectiel horizontaal gelanceerd wordt, zoals bij een bal die over een tafel rolt en aan het einde naar beneden begint te vallen, kon hij zijn argument voor de uniformiteit van de horizontale component inzetten. De baan van een projectiel dat in een hoek met de horizon gelanceerd wordt, zoals bijvoorbeeld het geval was in het experiment met Del Monte, is het resultaat van de samenstelling van een vrije valbeweging met een beweging volgens een niet-horizontale richting. Hoe die laatste beweging te karakteriseren bleef voor Galilei een raadsel (zie Damerow et al. (2004, pp. 216-236) voor een uitgebreide analyse van zijn gefaalde pogingen om hierop een antwoord te bieden).

De vierde dag van de Discorsi gebruikte de valwet om verschillende eigenschappen van de projectielbeweging aan te tonen, vertrekkende vanuit de parabolische vorm daarvan. Net zoals de derde dag was deze vierde dag geen onverdeeld succes. Galilei bewees de parabolische vorm van de baan van een projectiel strikt genomen enkel voor het geval van een horizontale projectie, en gebruikte niet verder beargumenteerde symmetrieoverwegingen om te suggereren dat de baan van elk ander projectiel ook parabolisch zou zijn.

\section{Waaraan ontlenen Galilei's experimenten hun bewijskracht?}

Galilei ontdekte zijn valwet waarschijnlijk op basis van een versie van het experiment zoals beschreven in zijn Discorsi. Dat wil echter niet zeggen dat we Koyré's scepticisme zomaar volledig aan de kant kunnen schuiven. Daarvoor moeten we eerst de verdere vraag beantwoorden in hoeverre

\footnotetext{
${ }^{10}$ De vroegste documentatie die we hebben van Galilei's overtuiging dat zo'n bewegingen eeuwigdurend zijn, komt uit een brief van een leerling van Galilei uit 1607 (Galilei, 1890, vol.10, p. 170).

${ }^{11}$ Het verdwijnen van de uitdovende kracht biedt meteen ook een opening om te begrijpen waarom een vallend object onder invloed van een constant uitgeoefende kracht (het gewicht van het object) een continue versnelling vertoont, eerder dan een constante snelheid zoals Galilei nog meende in De Motu Antiquiora. Een momentaan uitgeoefende kracht (zoals diegene die het object op een horizontaal vlak in beweging brengt) resulteert in een beweging met een snelheid die behouden blijft. Als er op dat bewegende object opnieuw dezelfde momentane kracht uitgeoefend wordt zal dat resulteren in een beweging met een verdubbelde snelheid. Door de constant uitgeoefende kracht te begrijpen als een continue opeenvolging van momentane krachten volgt de uniforme snelheidstoename die zich toont in de valwet.
} 
het voor Galilei en zijn tijdgenoten verantwoord was om op de resultaten van dat experiment te vertrouwen.

In het Europese natuurfilosofische netwerk uit de eerste helft van de zeventiende eeuw nam de Franse geestelijke Marin Mersenne een bijzondere plaats in. Hij onderhield een immense correspondentie met tal van geleerden, waaronder de filosoof René Descartes. Hij publiceerde ook verschillende collecties met wetenschappelijke ideeën en nam daarin ook de resultaten op van diverse experimenten die hij zelf uitvoerde. Als een van de eersten die de ideeën uit Galilei's bewegingstheorieën verder verspreidde, was de geldigheid van de valwet een terugkerend onderwerp van reflectie voor hem. ${ }^{12}$

Onmiddellijk nadat Mersenne in de Dialogo van Galilei uit 1632 de eerste publieke formulering van de valwet had gelezen, trachtte hij zelf de versnelling van vallende objecten te meten. Initieel overtuigde de uitkomst van zijn experimenten hem ervan dat die versnelling inderdaad door Galilei's valwet wordt gekarakteriseerd. In de jaren die volgden correspondeerde hij echter regelmatig over dat onderwerp, ook met wiskundigen en natuurfilosofen die een alternatieve valwet verdedigden, zoals de jezuïet Honoré Fabri. Die correspondenten waren op de hoogte van Galilei's stelling, maar meenden dat de experimenten mogelijke alternatieven niet uitsloten. Per slot van rekening waren de empirische resultaten slechts bij benadering in overeenstemming met Galilei's wet, en misschien waren er wel goede theoretische redenen om een andere wet te verkiezen. In het geval van Fabri was dat de overtuiging dat ruimte en tijd bestaan uit uitgebreide maar ondeelbare minima, met als gevolg dat elke versnelling stapsgewijs moet verlopen in plaats van continu. Bovendien kon Fabri aantonen dat voor relatief grote tijdsintervallen (en dat waren de enige die Galilei of Mersenne konden meten) het verschil tussen zijn wet en die van Galilei empirisch niet op te merken was. ${ }^{13}$ Op een soortgelijke manier wees Descartes Mersenne er herhaaldelijk op dat Galilei uitging van mogelijk betwistbare aannames met betrekking tot de oorzaak van het gewicht van objecten. Indien gewicht veroorzaakt wordt door voortdurende botsingen van zogenaamde "subtiele materie" met massieve objecten, zoals Descartes meende te kunnen aantonen, dan moeten we opnieuw besluiten dat de versnelling van zware

\footnotetext{
${ }^{12}$ De beschrijving van de evolutie in Mersennes ideeën die volgt, is gebaseerd op de gedetailleerde analyse in Palmerino (2010).

${ }^{13}$ De valwet van Galilei heeft als gevolg dat opeenvolgende afstanden afgelegd tijdens de valbeweging toenemen zoals de oneven getallen: als we de afstand gevallen na één tijdseenheid als eenheidsafstand nemen, dan zal het object na twee tijdseenheden vier keer zo ver gevallen zijn, na drie tijdseenheden negen keer zo ver, na vier tijdseenheden zestien keer zo ver, ... - het opeenvolgende verschil van die afstanden is drie, vijf, zeven, ... Volgens de door Fabri voorgestelde valwet nemen de afstanden toe zoals de gehele getallen. Wanneer de tijdseenheden erg klein gekozen worden, zullen voor relatief grote tijdsintervallen de verschillen tussen de verhoudingen van opeenvolgende afstanden verwaarloosbaar worden, en zeker niet gedetecteerd kunnen worden met de middelen die Galilei en Mersenne tot hun beschikking hadden.
} 
objecten niet continu kan verlopen maar schoksgewijs tot stand komt. In tegenstelling tot Fabri, die een alternatieve wiskundige wet naar voor schoof, meende Descartes dat het fenomeen van vrije val niet op een informatieve manier te mathematiseren viel. De botsingen van de ontelbare deeltjes subtiele materie zouden immers telkens lichtjes verschillende effecten met zich meebrengen in steeds veranderende en niet controleerbare omstandigheden. De uitkomst van dat soort debatten was dat Mersenne gaandeweg meer voorzichtigheid begon in te bouwen in zijn verdediging van Galilei's valwet tot hij in 1647 besloot dat we moeten stellen dat er "tot nu toe nog niets bewezen werd over versnelde beweging" (geciteerd in Palmerino (2010, p. 69)).

Het persoonlijke traject van Mersenne toont hoe de overtuigingskracht van experimentele resultaten mee bepaald wordt door de aan- of afwezigheid van alternatieve interpretaties. Of de resultaten "goed genoeg" waren om Galilei's valwet te ondersteunen hangt niet enkel af van de mate waarin ze overeenkwamen met die wet, maar ook van de vraag in hoeverre ze andere wiskundige interpretaties van die experimenten onwaarschijnlijk maakten. Dat is niet alles. Gegeven het feit dat de resultaten slechts bij benadering een wiskundige regelmaat vertonen, blijft de vraag open of dat al dan niet het gevolg is van een onderliggende wetmatigheid. Met voldoende inventiviteit zal het misschien altijd wel mogelijk zijn om een wiskundige formulering te vinden die de empirische resultaten op een min of meer benaderende manier samenvat. ${ }^{14}$ Waarom moeten we dan geloven dat die formulering ons iets kan leren dat meer is dan een samenvatting van die empirische resultaten zelf? Dat de resultaten van de experimenten bij benadering door Galilei's valwet beschreven kunnen worden, kan ook het gevolg zijn van de toevallige empirische omstandigheden waarin die objecten vallen. Galilei en Fabri meenden dat wanneer we alle storingen veroorzaakt door het medium waarin een object valt zouden kunnen wegnemen, dat we dan het "zuivere" fenomeen van vrije val zouden observeren, zoals gekarakteriseerd door hun respectieve valwetten. Descartes was er echter op principiële gronden van overtuigd dat er geen "zuiver" fenomeen te isoleren viel van de invloed van het medium. Volgens zijn opponenten getuigde de specifieke vorm van die benaderende wetten van een onderliggende wetmatigheid die potentieel geëxtrapoleerd kon worden naar andere fenomenen, volgens Descartes was dit niet meer dan een artefact van de omstandigheden waaruit er weinig informatiefs te leren viel over de aard van zware objecten.

Misschien was Koyrés stelling dat een metafysische oriëntatie de werkelijke grond vormde voor Galilei's vertrouwen in zijn valwet toch niet zo naast de kwestie. Hoe kon Galilei immers de alternatieve interpretaties van Fabri en Descartes uitsluiten, zonder zelf op niet-empirische aannames te steunen? Het mag dan een feit zijn dat hij experimentele metingen deed van valtijden en afstanden, het zou onverantwoord zijn geweest om te denken dat de resultaten van die metingen goed genoeg

\footnotetext{
${ }^{14}$ In de eenentwintigste eeuw is inventiviteit zelfs geen voorwaarde meer om aan curve fitting te kunnen doen, door de beschikbaarheid van computers.
} 
waren om tot de geldigheid van zijn valwet te besluiten zonder uit te gaan van bepaalde aannames over de aard van ruimte, tijd en causale wetmatigheden.

We zagen ondertussen echter ook waarom Galilei die metingen deed. Hij had goede redenen om aan te nemen dat er een zuiver fenomeen te vinden moest zijn, omdat zowel de parabolische baan van een projectiel als de isochronie van een slinger in sterke mate suggereerden dat de versnelling van vallende objecten een wiskundig te karakteriseren regelmaat moest vertonen. Geobserveerde projectielbanen zijn bij benadering parabolisch, slingers van gelijke lengte zijn bij benadering isochroon, en de tijden voor beweging op een hellend vlak zijn bij benadering kwadratisch. ${ }^{15}$ Elk van die individuele observaties laat veel ruimte voor interpretatie. Wat Galilei echter zag is dat de regelmaat in die fenomenen wederzijds informatief gemaakt kon worden door ervan uit te gaan dat al die benaderingen getuigen van onderling te relateren exacte wetten. Deze mogelijkheid om de observaties binnen het kader van één coherent onderzoeksprogramma te interpreteren was niet vanzelfsprekend en daarom ook bijzonder betekenisvol. Galilei's overtuiging dat zijn experiment met het hellende vlak voldoende ondersteuning bood om te vertrouwen op zijn valwet was dus niet enkel gegrond in de directe relatie tussen de resultaten van dat experiment en de vorm van zijn wet. Het experiment ontleende zijn bewijskracht aan zijn plaats binnen het ruimere onderzoeksprogramma. En door ervan uit te gaan dat die exacte wet zijn kwadratenwet was, kon hij inderdaad, zoals we zagen, enige vooruitgang boeken in dat onderzoeksprogramma.

De "metafysische" oriëntatie van Galilei toont zich dus in zijn besef dat het enkel mogelijk was om de wiskundige samenhang tussen fenomenen te onderzoeken door benaderende empirische wetten te interpreteren als symptoom van onderliggende zuivere fenomenen. Dat betekent ook dat de aanname dat we te maken hebben met een zuiver fenomeen maar verantwoord was in de mate dat ze het effectief mogelijk maakte om werkelijk vooruitgang te boeken in het blootleggen van de samenhang tussen verschillende empirische fenomenen.

De manier waarop de experimentele ondersteuning van Galilei's valwet geworteld was in zijn ruimere onderzoeksprogramma wordt nergens mooier geïllustreerd dan in het meest succesvolle experiment dat zijn neerslag vond in Galilei's manuscripten verzameld in Codex72 (zie figuur 3 ). ${ }^{16}$ In dat experiment plaatste Galilei een hellend vlak op een tafel. Hij liet ballen op dat vlak afdalen vanuit verschillende hoogtes (die we noteren als $h$ ), waarna ze op de tafel verder bewogen met de snelheid $v$

\footnotetext{
${ }^{15} \mathrm{Er}$ is nog een relatie tot een verder fenomeen die nog verdere ondersteuning bood aan zijn valwet, maar waarbij Galilei die relatie pas laat in zijn leven expliciet zou analyseren. Hij had experimenteel reeds vroeg vastgesteld dat de lengte van een slinger recht evenredig was met het kwadraat van de periode van die slinger. Ook hier kwam weer een kwadratische relatie naar voor, waarvan hij in een brief na de publicatie van de Discorsi aantoonde dat die wiskundig eenvoudig af te leiden was uit de valwet (Büttner, 2019, hoofdstuk 9).

${ }^{16}$ De hierna volgende beschrijving van het experiment op folio 116v steunt op Hahn (2002).
} 
die ze na tijd $t$ bereikt hadden onderaan het hellende vlak. Aan het uiteinde van de tafel werden de ballen horizontaal geprojecteerd met die snelheid, waarna Galilei noteerde welke horizontale afstand $R$ de ballen afgelegd hadden op het moment dat ze de grond raakten. De geometrie van het hellende vlak impliceert dat de afstand $s$ die een bal aflegt op het hellende vlak steeds proportioneel is met de hoogte $h$. Als de valwet geldt, dan moet die afstand ook proportioneel zijn met het kwadraat van de tijd $t$ die de bal op hellende vlak beweegt. Bovendien nemen in een eenparig versnelde beweging de snelheden toe zoals de tijden, dus moet $v$ ook proportioneel zijn met $t$. Eenmaal de bal horizontaal is beginnen bewegen met die snelheid zal volgens Galilei's analyse van een projectielbaan de horizontale component van de beweging uniform blijven, dus $R$ zal steeds proportioneel met $v$ moeten zijn (aangezien de valtijd onafhankelijk is van de horizontale beginsnelheid zal de bal steeds na dezelfde tijd de grond raken). Als we al die proporties samen nemen, dan weten we dat:

$$
h \sim s \sim t^{2} \sim v^{2} \sim R^{2}
$$

Door voor verschillende hoogtes $h$ de horizontale afstand $R$ te meten, kon Galilei de geldigheid van zijn aannames testen. De kleine afwijkingen die hij vond, kon hij plausibel toeschrijven aan verstoringen veroorzaakt door wrijving en luchtweerstand.

Het bijzondere aan dit experiment is dat het Galilei toeliet om een belangrijke bron van onnauwkeurigheid van het experiment beschreven in de Discorsi te elimineren door verschillende elementen uit zijn onderzoeksprogramma tegelijkertijd te testen. In het experiment uit de Discorsi vergeleek hij de beweging op een hellend vlak met een ander fenomeen waarvan hij moest aannemen dat het een uniforme tijdmaat bood, en waarbij zich het extra probleem stelde dat die tijdmetingen gecorreleerd moesten worden met de bewegingen (hoe te garanderen dat de waterklok exact gelijktijdig met de beweging van de bal begint en stopt?). In het experiment van folio $116 \mathrm{v}$ is de tijdmeting intern aan de bestudeerde fenomenen gemaakt, en hoeft er geen externe klok meer gebruikt te worden.

Door uit te gaan van het uniforme karakter van de neutrale beweging kan de afstand $R$ gebruikt worden om de snelheid $v$ te meten, om op die manier te testen of die snelheid inderdaad toeneemt op de manier voorspeld door de valwet. Omgekeerd kan uitgegaan worden van de valwet, waardoor de hoogte $h$ gebruikt kan worden om de snelheid $v$ te bepalen, om op die manier te toetsen of een neutrale beweging effectief uniform is. Impliciet in het experiment zijn er dus twee verschillende klokken (respectievelijk de neutrale beweging en de versnelde valbeweging), die allebei gebruikt kunnen worden om de snelheid $v$ te meten. Dat het experiment goede resultaten opleverde, toont aan dat die twee klokken wederzijds gekalibreerd kunnen worden: hun respectieve tijdmetingen kunnen onderling inwisselbaar gemaakt worden. Dit is het moment waarop de mathematisering van tijdsverloop werkelijk aanvang nam.

\section{Hoe de valwet verder informatief te maken}


Als de empirische ondersteuning van de valwet essentieel afhangt van de vruchtbaarheid van Galilei's ruimere onderzoeksprogramma, dan is het slechts partiële succes van de in de Discorsi bereikte resultaten bijzonder significant. Als de beperkingen van Galilei's resultaten niet overwonnen konden worden, dan was de ondersteuning van de valwet ook niet bijzonder sterk. De vraag in hoeverre het verantwoord was om op de valwet te vertrouwen kan dus enkel beantwoord worden door te kijken naar de successen van onderzoek na Galilei waarin diezelfde exacte wet verondersteld werd.

De belangrijkste doorbraak op dit vlak vond plaats in december 1659 en werd geleverd door de Nederlandse wiskundige Christiaan Huygens. ${ }^{17}$ Uitgaande van dezelfde fysische veronderstellingen als Galilei, waaronder cruciaal de valwet, maar met meer gesofisticeerde wiskundige technieken tot zijn beschikking, was Huygens in staat om aan te tonen dat uit die veronderstellingen volgt dat een slinger perfect isochroon zou zijn indien hij een deel van het pad van een omgekeerde cycloïde volgt in plaats van een cirkelvormig pad zoals Galilei meende. ${ }^{18}$ Bovendien impliceerde Huygens' bewijs dat een cirkelvormige slinger enkel dicht bij isochronie blijft voor kleine uitwijkingen, in overeenstemming met wat reeds door Galilei's tijdgenoten geobserveerd werd. In het geval van de isochronie waren de afwijkingen van het veronderstelde zuivere fenomeen (isochronie voor een cirkelvormige slinger) dus niet zomaar toe te schrijven aan verstoringen, maar maskeerden ze een onderliggend relevant fenomeen. Zoals Huygens wist aan te tonen, is het empirische feit dat een cirkelvormige slinger alleen voor kleine cirkelbogen isochroon is, wel degelijk informatief voor de onderliggende wetmatigheid (dat de exacte isochronie enkel geldt voor een cycloïdische slinger).

Door effectief een cycloïdische slinger te construeren, kon empirisch geobserveerd worden dat die inderdaad veel preciezer dan een cirkelvormige slinger isochronie behoudt voor verschillende booglengtes. Bovendien volgde uit het wiskundige bewijs dat de periode van een slinger exact uitgedrukt kan worden in termen van de lengte van de slinger en een bijzondere grootheid die de constante valversnelling uitdrukt: de afstand die een object in vrije val aflegt gedurende de eerste seconde van zijn beweging. De periode van een slinger kon empirisch gekalibreerd worden met de astronomische tijd die bepaald wordt door de opeenvolgende passages van een hemellichaam aan dezelfde plaats relatief ten opzichte van aarde (met elke passage komt vierentwintig uur overeen), zodanig dat de slinger perfect astronomische secondes zou meten. Uit de lengte van die slinger kon onmiddellijk berekend worden wat de grootte van de valversnelling is. Dit betekende ook dat de wiskundige klok impliciet in de valwet nu voor de eerste maal op een exacte manier gerelateerd kon worden aan de astronomische klok, die al sinds de aanvang van het leven alle relevante tijdsverloop mat.

\footnotetext{
${ }^{17}$ Zie Yoder (1988) en Mahoney (2000) voor gedetailleerde analyses.

${ }^{18}$ Een cycloïde is de curve die ontstaat door een punt te volgen op een cirkel die op een horizontaal vlak rolt. Later in de zeventiende eeuw zou door verschillende auteurs aangetoond worden dat de cycloïde ook de brachistochroon is.
} 
Zoals Koyré reeds concludeerde in zijn tekst waarin hij provocatief de waarde van Galilei's experimenten in vraag stelde, bood het gedrag van Huygens' slinger de eerste werkelijk precieze confirmatie voor de valwet. Tegelijkertijd toonde ze ook dat de valwet nog verder informatief gemaakt zou kunnen worden, ditmaal voor astronomische fenomenen. Als de tijden gemeten door vallende objecten het gevolg zijn van een beweging onder een constante kracht, dan is het plausibel dat de tijden gemeten door astronomische objecten op een vergelijkbare manier geïnterpreteerd kunnen worden. Dat is echter een ander verhaal, het verhaal over hoe Newton zijn gravitatiewet ontdekte. ${ }^{19}$

Newtons Principia Mathematica en Huygens' ontdekking van de exacte vorm van de isochrone slinger tonen de buitengewone kracht van wiskundige technieken om zoveel mogelijk informatie uit de empirische regelmaat van fenomenen te halen. Huygens was in staat om nieuwe resultaten uit gekende empirische feiten af te leiden door te tonen hoe de wiskundige representatie van die feiten een structuur had die verder geanalyseerd kon worden. Op een vergelijkbare manier exploiteerde Newton wiskundige relaties om de beschikbare empirische informatie over astronomische fenomenen op een zo vruchtbare mogelijke manier te interpreteren en systematisch uit te diepen. Galilei's ontdekking van de valwet bleek de sleutel waarmee een bijzonder succesvolle wiskundige informatiemachine opgestart kon worden - een sleutel die niet enkel lag in de specifieke vorm van de wet, maar vooral in de manier waarop die van bij aanvang ingebed zat in een ruimer onderzoeksprogramma.

\section{Referenties}

Büttner, J. (2019). Swinging and Rolling. Unveiling Galileo's unorthodox path from a challenging problem to a new science. Dordrecht: Springer.

Damerow, P., Freudenthal, G., McLaughlin, P. \& Renn, J. (2004). Exploring the Limits of Preclassical Mechanics. New York, NY: Springer New York.

Drake, S. (1973). Galileo's Experimental Confirmation of Horizontal Inertia: Unpublished Manuscripts. Isis, 64, 290-305.

Fredette, R. (2001). Galileo's De motu antiquiora: Notes for a Reappraisal. In J. Montesinos \& C. Solis Santos (red.), Largo Campo di Filosofare (pp. 165-181). La Orotava: Fundacion Canaria Orotava de Historia de la Ciencia.

Galilei, G. (1890). Le Opere di Galileo Galilei (A. Favaro, red.). Firenze: Barbera.

Hahn, A. J. (2002). The Pendulum Swings Again: A Mathematical Reassessment of Galileo's Experiments with Inclined Planes. Archive for History of Exact Sciences, 56(4), 339-361.

\footnotetext{
${ }^{19}$ Dit verhaal is al door verschillende auteurs verteld; zie Smith (2002) en Harper (2002) voor goede vertrekpunten - zie ook Ducheyne (dit volume).
} 
Harper, W. (2002). Newton's Argument for Universal Gravitation. In I. B. Cohen \& G. E. Smith (red.), The Cambridge Companion to Newton (pp. 174-201). Cambridge: Cambridge University Press.

Koyré, A. (1953). An Experiment in Measurement. Proceedings of the American Philosophical Society, 97(2), 222-237.

Mahoney, M. S. (2000). Huygens and the Pendulum: From Device to Mathematical Relation. In E. Grosholz \& H. Breger (red.), The Growth of Mathematical Knowledge (pp. 17-39). Dordrecht: Springer Netherlands.

Palmerino, C. R. (2010). Experiments, Mathematics, Physical Causes: How Mersenne Came to Doubt the Validity of Galileo's Law of Free Fall. Perspectives on science, 18(1), 50-76.

Renn, J., Damerow, P., Rieger, S. \& Giulini, D. (2000). Hunting the White Elephant: When and How did Galileo Discover the Law of Fall? Science in Context, 13(3-4), 299-419.

Settle, T. B. (1961). An Experiment in the History of Science. Science, 133(3445), 19-23.

Smith, G. E. (2002). The Methodology of the Principia. In I. B. Cohen \& G. E. Smith (red.), The Cambridge Companion to Newton (pp. 138-173). Cambridge: Cambridge University Press.

Van Dyck, M. (2018). Idealization and Galileo's Proto-Inertial Principle. Philosophy of Science, 85(5), 919-929.

Yoder, J. G. (1988). Unrolling Time: Christiaan Huygens and the Mathematization of Nature. Cambridge: Cambridge University Press.

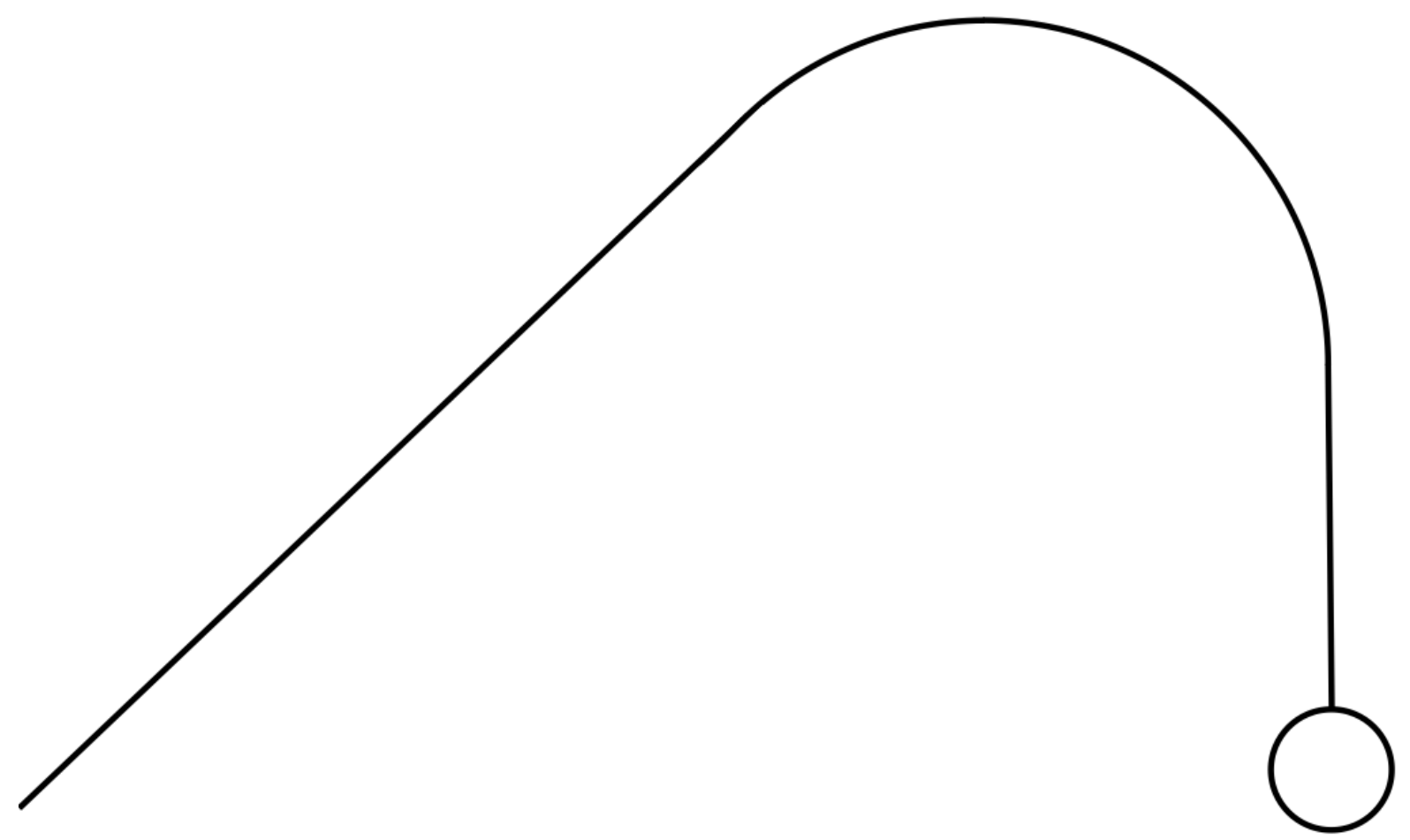

Figuur 1. De baan afgelegd door een kanonskogel volgens De Motu Antiquiora. 


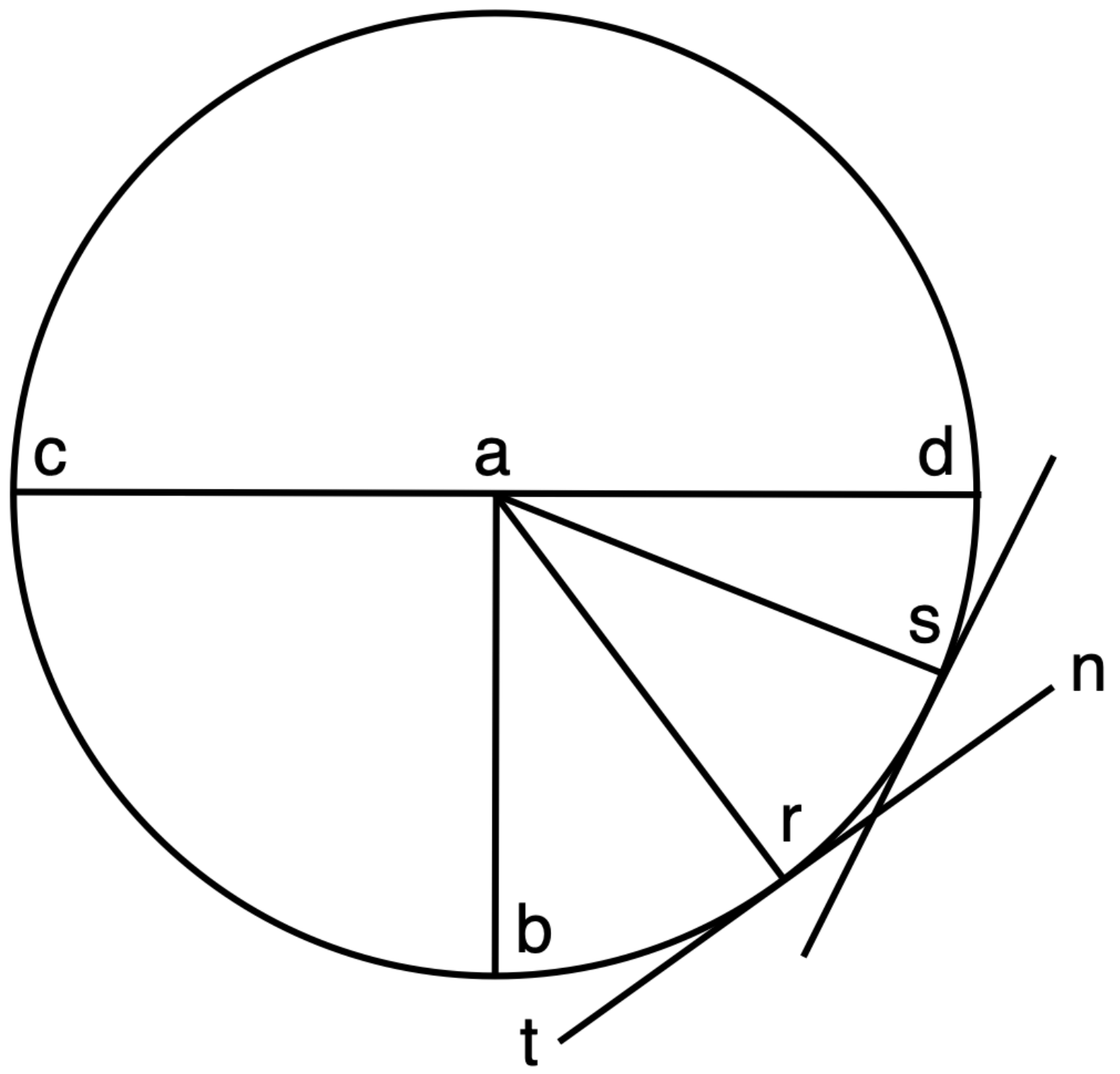

Figuur 2: Bepaling van het effectieve gewicht op een hellend vlak. Een object op hellend vlak tn kan met behulp van de balans car (met gebogen arm ar) in evenwicht gehouden worden door een gewicht in $c$. De wetten voor een balans met gebogen arm (en wat eenvoudige trigonometrie) leren dat de verhouding van het effectieve gewicht van het object in $r$ tot zijn absolute gewicht dezelfde is als die van de hoogte van het hellende vlak tot de lengte ervan. (Diagram uit De Motu Antiquiora van Galilei.) 


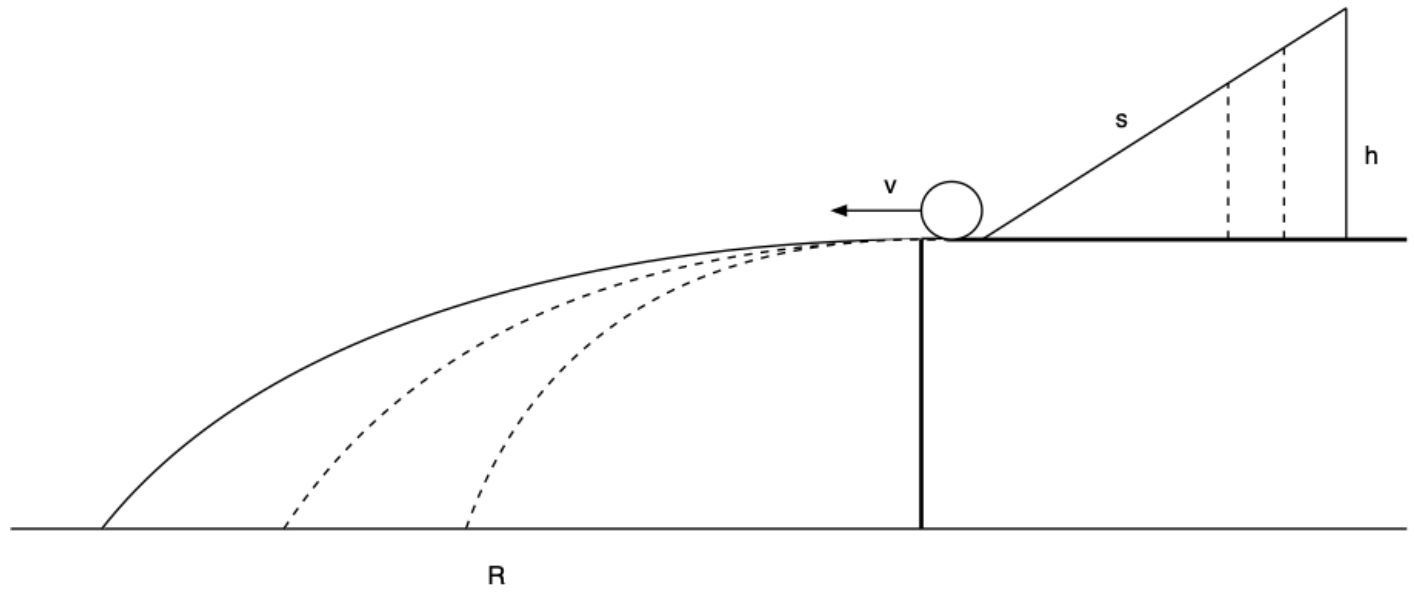

Figuur 3: Het experiment van folio 116v uit Codex 72. 